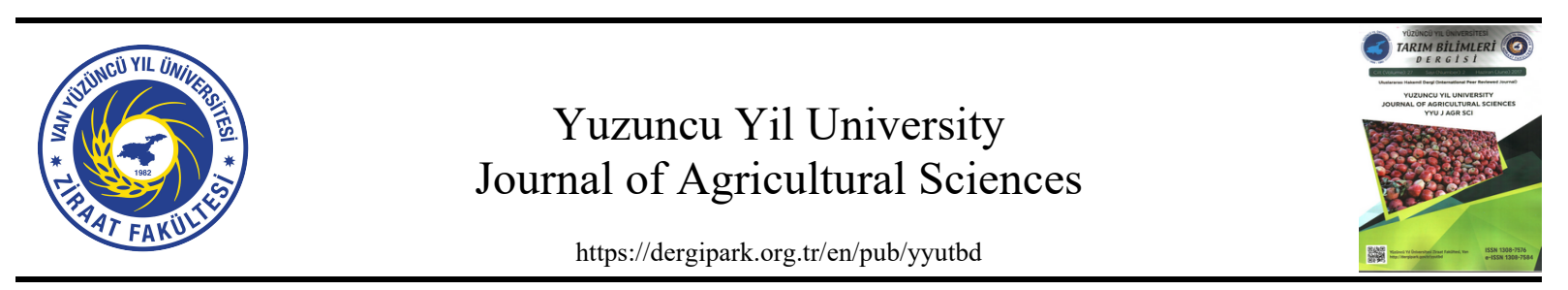

Research Article

\title{
Red Meat Price Volatility and Its Relationship with Crude Oil and Exchange Rates in Turkey with the Approach of GARCH (p, q) Model
}

\author{
Melek AKAY ${ }^{* 1}$ \\ ${ }^{1}$ Agricultural Engineer, General Directorate of Agricultural Research and Policy, 06800 Ankara, Turkey \\ ${ }^{1}$ https://orcid.org/0000-0002-8717-0699 \\ *Correspondence author e-mail: melek.akay@tarimorman.gov.tr
}

\section{ArticleInfo}

Received: 18.08 .2021

Accepted: 25.10.2021

Online Published: 15.12 .2021

DOI: 10.29133 /yyutbd.984277

\section{Keywords}

Crude Oil,

Exchange Rates,

GARCH $(p, q)$ models,

Red Meat Prices,

Volatility,

Turkey.

\begin{abstract}
Turkey's agricultural commodity prices are volatile while they have steadily increased over time. A substantial amount of research has been done on the variations in these prices by looking at other commodities like energy. As a result, the connections between agricultural and energy markets have been widely explored. There is a great concern about how red meat prices in Turkey are getting increasingly fluctuating. On the other hand, we may assume that ups and downs movement in the prices of crude oil and exchange rates are connected to veal and lamb carcass prices and that volatility is transmitted to those meat prices. This study uses the generalize all period unconstraint volatility model, which generalizes the GARCH (p, q) model, to examine the veal and lamb prices volatilities in Turkey and their relationship with crude oil as well as exchange rates (data are weekly covering from May 2006 to February 2017). According to findings, red meat prices have been volatile over the previous decade, notably between 2009 and 2012. Furthermore, crude oil prices have an important impact on the prices of veal and lamb and their prior times statistically. Also exchange rates at $\mathrm{t}-2$ and $\mathrm{t}-4$ time have an impact on lamb prices but none at all on veal prices. Subsequently, red meat price rise and volatility are becoming an important problem for Turkey, and the policies made in this area need to be evaluated.
\end{abstract}

\section{Türkiye'de Kırmızı Et Fiyatı Oynaklığı ve Kırmızı Et Fiyatlarının Ham Petrol ve Döviz Kurları ile İlişkisi, GARCH (p, q) Modeli Yaklaşımı}

\section{Makale Bilgileri}

Geliş: 18.08 .2021

Kabul: 25.10.2021

Online Yayınlanma: 15.12.2021

DOI: $10.29133 /$ yyutbd.984277

\section{Anahtar Kelimeler}

Ham Petrol,

Döviz Kuru,

GARCH (p, q) Modeli,

Kırmızı Et Fiyatları,

Volatilite,

Türkiye.
Öz: Türkiye'nin tarımsal ürün fiyatlarında genel olarak bir yükselme ile birlikte zaman içerisinde oynaklıklar görülmektedir. Fiyatlarda görülen bu oynaklıklar önemli çalışma konularından biridir. Özellikle, sıkça değiş̧en enerji fiyatları ile tarımsal ürünlerin fiyatları arasındaki ilişki bilimsel olarak incelenmiştir. Türkiye'de kırmızı et fiyatlarının nasıl giderek dalgalandığı konusu ise önem arz etmektedir. Ayrıca, ham petrol fiyatlarındaki ve döviz kurlarındaki iniş çıkışların kırmızı et fiyatlarına bağlı olduğunun yanı sıra ham petrol ve döviz kurlarındaki oynaklı̆̆ın kırmızı et fiyatlarına yansıdı̆̆ını varsayabiliriz. Genel olarak, normal doğrusal regresyon analizi ile GARCH (p, q) model kullanılarak dana ve kuzu karkas, ham petrol ve döviz kuru fiyatları arasındaki ilişki ve kırmızı et fiyatı volatilitesi son on yıllık veriler dikkate alınarak incelenmiştir (veriler haftalık veriler olup Mayıs 2006 ve Şubat 2017 periyodunu kapsamaktadır). Analiz sonuçlarına bakıldığında, dana ve kuzu karkas fiyatlarının son on yıllık süreçte oynaklık gösterdiği, özellikle 2009- 2012 yılları (ithalatın yüksek oranda yapıldığı dönem) arasında yüksek oynaklık tespit edilmiştir. Aynı zamanda, petrol fiyatları ile çok önemli bir ilişkiye sahip olduğu belirlenmiş ve t-2, t-4 zamandaki döviz kuru fiyatı kuzu karkas fiyatını etkilerken dana karkas ile önemli bir ilişkisi bulunmamıştır. Sonuç olarak, kırmızı et fiyat yükselişi ve 
oynaklıkları Türkiye için önemli bir problem haline gelmekte ve bu alanda yapılan politikaların değerlendirilmesi gerekmektedir.

\section{Introduction}

Livestock is an essential sector for consumers and producers in Turkey since it offers a wellbalanced diet and income source. The government has made concerted efforts to encourage agricultural productivity improvement at all levels through various programs, with consideration of the livelihood of the rural population. One of the main objectives of the policies, particularly those of the central government, is to minimize and stabilize the continuously rising costs of red meat, which have grown exorbitant in recent years (USDA, 2016). Therefore, livestock is regarded as one of Turkey's most crucial sub-sectors.

It is fact that many countries' economies are heavily reliant on livestock production. In Turkey, its share in the entire agricultural sector is 36.3 percent (TIM, 2017). Red meat prices have risen steadily in recent years with fluctuation, and they have trebled in the previous decade (TUIK, 2017). It is observed that the prices of veal carcass per kilogram climbed from roughly 8 TL to 24 TL between 2006 and 2016, while lamb carcass prices increased within the same proportion. Agricultural commodity price rises and volatility, according to Hayenga and Dipietre (1982), have an impact on all market sectors. As a result, the feasibility of red meat prices is to be a heated issue among consumers, producers, and politicians, as predicted.

Chadwick and Baştan (2017) study the volatility of beef prices in Turkey and recommend that agricultural price volatility be studied using a range of factors. Yavuz et al. (2013) have discussed the implications of policies in Turkey's red meat sector. They suggest that Turkey has moved to help producers more and import more red meat as live animal or products to decrease the prices and maintain market prices stability. The factors that influence red meat prices, as well as the links between red meat and other commodity prices, have received a lot of attention in this context. We selected crude oil prices and exchange rates to determine the possible link between those and red meat prices.

Because a country heavily imports crude oil, which is an input factor in agriculture, volatility transfer from the prices of red meat to exchange rates or the exact opposite is possible. According to the Republic of Turkey Ministry of Foreign Affairs (2017), the indigenous energy supplies are limited, so Turkey's energy imports are becoming increasingly reliant on gas as well as oil. In this context, Nazloglu et al. (2012) suggest that the exchange rate is connected to the indirect effect of crude oil prices on agricultural commodity prices. Thus, the value of the dollar in relation to the local currency (TL) may be linked to the expenses of feeding livestock, along with transportation and processing. Furthermore, imported red meat and live animals have been allowed since 2010, and it is currently being questioned if exchange rate prices are being transferred to the meat market. In conclusion, crude oil and the exchange rate are predicted to be exogenous variables in the model. As shown in Fig. 1, there may be a relationship between red meat and the oil market, and the red meat market and exchange rates, although this research does not acquire import data to support our hypothesis. We'll look at the prices in Turkish Lira (£) against US dollars (\$). (note that Figure 1 is given based on the assumption of this study).

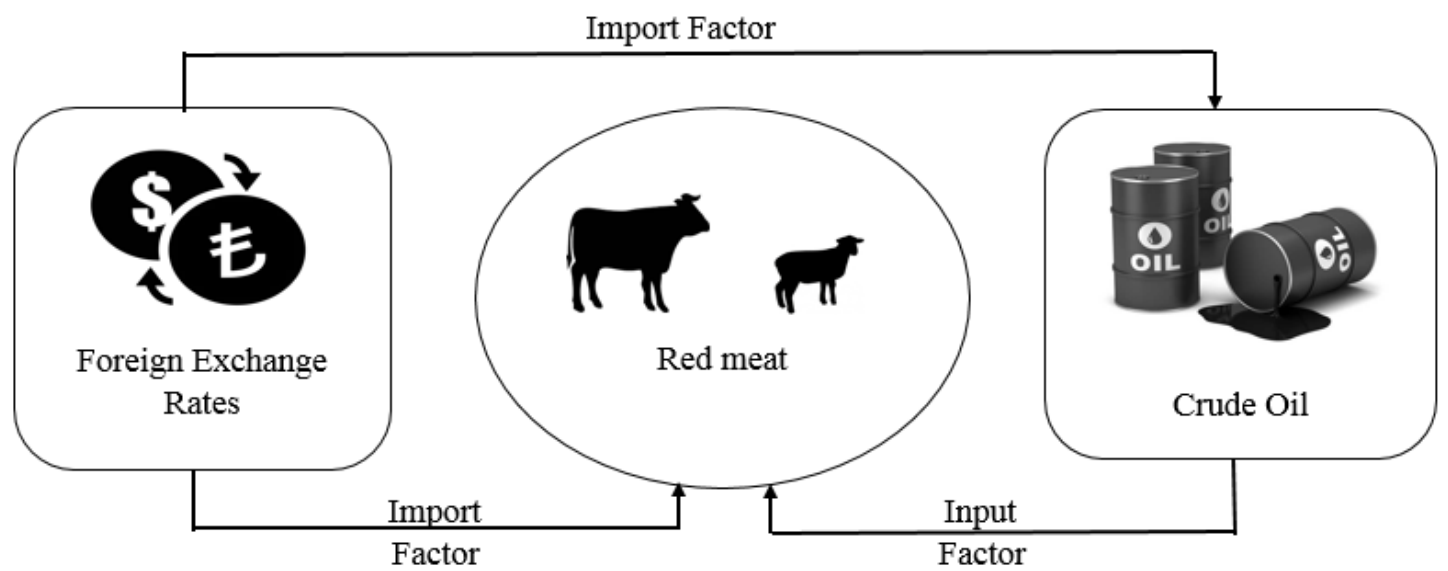

Figure1. Possible link between red meat, crude oil, and exchange rates in Turkey. 


\subsection{Research objectives}

In a temporal dimension, the variation of red meat prices may not be constant, and rather it may exhibit fluctuation. As a result, it is hypothesized that there can be a link between this shift and changes in the exchange rate and crude oil price variables, and this study seeks to uncover this presumed link. The primary goal of this study is to determine if veal and lamb prices are volatile, as well as the relation between red meat prices and exchange rates, crude oil prices.

\section{Literature Review}

A considerable number of studies have been done on the volatility of agricultural prices. These studies were conducted from various perspectives and approaches in relation to certain commodity prices in agriculture and energy markets, such as maize, soybeans, crude oil, and biofuel. To assess the fluctuation of prices and to describe the influence of oil prices as an input cost on the agricultural sector, this literature has used a range of statistical approaches or models to illustrate the link between the agricultural commodities and energies empirically in a manner of economic sense. Furthermore, a significant number of researches have been published in the case of the association with the relationship of the agricultural and energy commodities as well as price volatility transmission between those commodities.

Table 1 shows the literature of econometrics models utilized in our research for volatility and price transmission. 
Table 1. Summary of literature surveyed

\begin{tabular}{|c|c|c|c|c|}
\hline Authors & Data & Methodologies* & Variables & Main Result \\
\hline $\begin{array}{l}\text { Serra and Goodwin } \\
\text { (2003) }\end{array}$ & $\begin{array}{l}\text { July } 1994 \text { to December } 2000 \\
\text { (monthly) }\end{array}$ & The multivariate TVECMs & dairy prices & $\begin{array}{l}\text { A part of the raw milk processed is conspicuously affected by asymmetries although } \\
\text { asymmetries do not exist in the price transmission of daily products that is highly } \\
\text { perishable. }\end{array}$ \\
\hline $\begin{array}{l}\text { Hassan and Malik } \\
\text { (2007) }\end{array}$ & $\begin{array}{l}\text { January } 1,1992 \text { to June } 6 \\
2005 \text { (daily) }\end{array}$ & $\begin{array}{l}\text { VECH, and BEKK } \\
\text { parameterizations. }\end{array}$ & $\begin{array}{l}\text { financial, industrial, consumer } \\
\text { (services), health, energy (oil and } \\
\text { gas), and technology sectors } \\
\text { indexes }\end{array}$ & An important shock and volatility transmission is present among several sectors \\
\hline Harri et al., (2009) & $\begin{array}{l}\text { January } 2000 \text { to September } \\
2008 \text { (monthly) }\end{array}$ & The co-integration model & $\begin{array}{l}\text { corn, soybeans, soybean oil, cotton } \\
\text { and wheat, exchange rates, and oil } \\
\text { prices }\end{array}$ & $\begin{array}{l}\text { There is a linkage between oil and agricultural commodity prices, but not wheat and } \\
\text { exchange rates have a role in prices. }\end{array}$ \\
\hline Kaltalıglu (2010) & $\begin{array}{l}\text { January-1998 to February- } \\
2009 \text { (monthly) }\end{array}$ & $\begin{array}{l}\text { The co-integration tests, VAR } \\
\text { model }\end{array}$ & $\begin{array}{l}\text { maize, wheat, soybean, rice, and } \\
\text { oil spot prices }\end{array}$ & $\begin{array}{l}\text { There is a relationship between oil returns and agricultural commodity returns in the } \\
\text { case of volatility spillover. }\end{array}$ \\
\hline $\begin{array}{l}\text { Hassouneh et al. } \\
(2010)\end{array}$ & $\begin{array}{l}\text { January } 1996 \text { to December } \\
2005 \text { (monthly) }\end{array}$ & VECM & beef prices & Beef producers and retailers are differently affected by BSE scares. \\
\hline $\begin{array}{l}\text { Nazlioglu \& Soydas, } \\
(2012)\end{array}$ & $\begin{array}{l}\text { January } 1980 \text { to February } \\
2010 \text { (monthly) }\end{array}$ & $\begin{array}{l}\text { A panel co-integration, } \\
\text { causality analysis }\end{array}$ & $\begin{array}{l}24 \text { agricultural commodities, oil, } \\
\text { and exchange rates }\end{array}$ & $\begin{array}{l}\text { The changes in the world oil prices affect the agricultural commodity prices, and } \\
\text { exchange rates had a weak effect on agricultural prices. }\end{array}$ \\
\hline Nazloglu et al. (2013) & $\begin{array}{l}\text { 01 January } 1986 \text { to } 21 \text { March } \\
2011 \text { (daily) }\end{array}$ & Causality test & $\begin{array}{l}\text { spot prices of world oil, corn, } \\
\text { soybeans, wheat, and sugar }\end{array}$ & $\begin{array}{l}\text { The food price crisis has an effect on the changes in the dynamic of volatility } \\
\text { transmission. }\end{array}$ \\
\hline Serra \& Gil (2013) & $\begin{array}{l}\text { 01 January } 1990 \text { to } 01 \\
\text { January } 2011 \text { (daily) }\end{array}$ & Multivariate GARCH model & corn and ethanol prices & There is a price volatility transmission between ethanol and corn markets \\
\hline $\begin{array}{l}\text { Gardebroek \& } \\
\text { Hemordez (2013) } \\
\end{array}$ & 1997 and 2011 (annually) & $\begin{array}{l}\text { BEKK-GARCH model, } \\
\text { DCC-GARCH model }\end{array}$ & oil, ethanol, and corn prices & There is a significant interaction between ethanol and corn prices \\
\hline An et al. (2016) & $\begin{array}{l}\text { January } 2005 \text { to June } 2013 \\
\text { (weekly) }\end{array}$ & $\begin{array}{l}\text { Multivariate GARCH model, } \\
\text { asymmetric VECBEKK- } \\
\text { GARCH }\end{array}$ & wheat and flour prices & $\begin{array}{l}\text { Export has a role in the decrease in the transmission elasticity by } 25 \% \text { in flour and } \\
\text { wheat markets }\end{array}$ \\
\hline Bergman et al. (2016) & $\begin{array}{l}\text { January } 1995 \text { to December } \\
2015 \text { (monthly) }\end{array}$ & $\begin{array}{l}\text { VAR model, Multivariate } \\
\text { GARCH }\end{array}$ & $\begin{array}{l}\text { Butter, crude oil, and crude palm } \\
\text { oil prices from }\end{array}$ & $\begin{array}{l}\text { The effects of price and volatility transmission are present between EU and World } \\
\text { butter prices }\end{array}$ \\
\hline $\begin{array}{l}\text { Cinar \& Hushmat } \\
\text { (2016) }\end{array}$ & 1995 to 2015 (monthly) & GARCH models are & world oil and Turkey's food prices & $\begin{array}{l}\text { Volatility spillover between oil and auto, power, and finance sectors, but it is not } \\
\text { significant in case of Indian stock markets }\end{array}$ \\
\hline $\begin{array}{l}\text { Chadwick and Bastan } \\
\text { (2017) }\end{array}$ & $\begin{array}{l}\text { January } 2003 \text { to November } \\
2016 \text { (monthly) }\end{array}$ & $\begin{array}{l}\text { Univariate GARCH and } \\
\text { Multivariate DCC-GARCH }\end{array}$ & $\begin{array}{l}\text { producer prices for cattle, } \\
\text { consumer prices for the veil, and } \\
\text { cattle imports prices }\end{array}$ & $\begin{array}{l}\text { The food prices in Turkey are significantly affected by the global oil prices, and also, } \\
\text { the food price volatility is affected by the oil price shocks. }\end{array}$ \\
\hline Damba et al. (2017) & $\begin{array}{l}\text { January } 1990 \text { to September } \\
2015 \text { (monthly) }\end{array}$ & $\begin{array}{l}\text { Multivariate BEKK-GARCH } \\
\text { model }\end{array}$ & $\begin{array}{l}\text { the world meat, dairy, cereal, } \\
\text { edible oil, sugar }\end{array}$ & $\begin{array}{l}\text { The effect of import on beef prices is captured by Univariate GARCH models as well } \\
\text { as multivariate GARCH model }\end{array}$ \\
\hline
\end{tabular}

*Where TVECMs: Threshold Vector Error Correction Models, VECH: Vector Error Correction Model, BEKK-GARCH: Baba, Engle, Kraft and Kroner GARCH Model, VAR: Vector Autoregressive Model, MGARCH: Multivariate GARCH Model, DCC-GARCH: Dynamic Conditional Correlation in GARCH Model. 


\section{Methodology and Data Source}

Prices of veal carcass, lamb carcass, exchange rates, and crude oil in Turkey are utilized weekly for the analysis by obtaining the period from May 2006 to February 2017. All variables are expressed in Turkish Lira (TL), and we exclude international oil prices since the world oil prices are somewhat different than the local oil prices -most probably, this is because of taxes-. Furthermore, the data is collected on a daily basis, but it is transformed to a week by averaging the values of each week from Monday to Friday. These red meat prices data come from the Turkish Commodity Exchanges Information Systems (TOBB), while exchange rates and crude oil prices come from the Turkish Central Bank (TMB) and the Republic of Turkey Energy Market Regulatory (EPDK), respectively.

The variables data are nominal, but they are changed to real prices which are deflated by dealing with consumer price indices (CPI) considering the variables in February 2017 (TUIK, 2017) which is the last period of data. The dataset obtains 562 observations. A few missing values of variables exist in data, but those are settled by getting the average of the previous and next one values.

\subsection{Augmented Dickey-Fuller Unit root tests}

Dickey \& Fuller (1979) created the Augmented Dickey-Fuller (ADF) unit root tests to determine if the regression is stationary or non-stationary. While it is widely acknowledged that the unit root tests are a legitimate test for confirming stationarity in time series analysis (Enders, 2015), it is a useful test for analyzing stationarity structure and lag length choices. The equation of ADF tests are given below,

$$
\begin{gathered}
\Delta \mathrm{Y}_{\mathrm{t}}=\alpha+\theta \mathrm{Y}_{(\mathrm{t}-1)}+\sum_{\mathrm{i}=1}^{\mathrm{p}} \delta_{\mathrm{i}} \Delta \mathrm{Y}_{(\mathrm{t}-\mathrm{i})}+\mathrm{u}_{\mathrm{t}} \\
\Delta \mathrm{Y}_{\mathrm{t}}=\mathrm{t}+\alpha+\theta \mathrm{Y}_{(\mathrm{t}-1)}+\sum_{\mathrm{i}=1}^{\mathrm{p}} \delta_{\mathrm{i}} \Delta \mathrm{Y}_{(\mathrm{t}-\mathrm{i})}+\mathrm{u}_{\mathrm{t}}
\end{gathered}
$$

where $Y_{t}$ indicates a time series investigating at time t, and $\Delta Y_{t}$ denotes $Y_{t}$ 's differences, and the error term is $u_{t}$. The deterministic intercept is included in equation (1), but the deterministic trend is also included in equation (2). The error term's mean is assumed to be zero, and the white noise is applied as the error term, which does not have a constant variance throughout the time series. Dickey and Fuller (1979) indicate that if $|\theta|$ is equal and more than 1 , non-stationary occurs for the variable, but if $|\theta|$ is greater than 1, the variable is stationary. Furthermore, if a unit root occurs in the time series, it is nonstationary, or vice versa (Harris and Sollis, 2003). The following conditional is going to be examined.

Null Hypothesis $\left(\mathrm{H}_{0}\right)$ : The variable includes unit root

Alternative Hypothesis $\left(\mathrm{H}_{1}\right)$ : Variable is stationary

Furthermore, when the probability value(p-value) is evaluated, the variables in the equation are stable at significant levels (it is less than at least 0.1 significant level), then the null hypothesis by using the p-value in the model will be rejected. If the model is not stationary, the first step is to take the initial differences of the variable in a manner of the model stationary for volatility estimates.

After that, the lag number for each variable will be considered as the value of each variable in the previous period. As seen in the ADF test equations (1) and (2), lag length can range from $p=1,2$, $3, \ldots, n$. The selection of lag length, on the other hand, is dependent on various criteria, but the AIC is used to determine the lag length.

\subsection{ARCH effects tests}

The ARCH effects test is used to look at the estimation of residuals in a model. The heteroscedasticity of the regression is examined using this test. In theory, the ARCH effect is tested in two ways. First, we must do a standard linear regression and then store the residuals $\left(\hat{u}_{t}\right)$. Second, the residuals are squared and regressed using the ARCH (q) models' q own lags, before running the regression in equation (3). 


$$
\begin{aligned}
& \mathrm{y}_{\mathrm{t}}=\beta_{0}+\beta_{1} \mathrm{x}_{1 \mathrm{t}}+\beta_{2} \mathrm{x}_{2 \mathrm{t}}+\beta_{3} \mathrm{x}_{3 \mathrm{t}}+\mathrm{u}_{\mathrm{t}} \\
& \hat{\mathrm{u}}_{\mathrm{t}}^{2}=\gamma_{0}+\gamma_{1} \hat{\mathrm{u}}_{\mathrm{t}-1}^{2}+\gamma_{2} \hat{\mathrm{u}}_{\mathrm{t}-2}^{2}+\cdots+\gamma_{\mathrm{q}} \hat{\mathrm{u}}_{\mathrm{t}-\mathrm{q}}^{2}+\varepsilon_{\mathrm{t}}
\end{aligned}
$$

Following this equation, we should calculate $R^{2}$, and $T R^{2}$-the test statistic-, where the number of observations is T. Lastly, we examine the null hypothesis in comparison to the alternative hypothesis listed below.
$\mathrm{H}_{0}: \gamma_{0}=0, \gamma_{1}=0$ and $\gamma_{2}=0 \ldots$ and $\gamma_{\mathrm{q}}=0$
There are no ARCH effects
$\mathrm{H}_{1}: \gamma_{0} \neq 0$ or $\gamma_{1} \neq 0$ or $\gamma_{2} \neq 0$... or $\gamma_{\mathrm{q}} \neq 0$
There are ARCH effects

In consequence, if the critical value of the Chi-square distribution $\left(\chi^{2}\right)$ is smaller than $T R^{2}$ in the ARCH effects test, the null hypothesis will be rejected, which it indicates that the ARCH effect exists in the regression. We may use the GARCH model for our regression after determining the presence of ARCH effects.

\subsection{GARCH (p, q) model tests}

The conditional variance in the GARCH model is dependent on own prior lags and squared error in prior periods of time. When comparing the GARCH and ARCH models, it appears that the GARCH models are widely used and more convenient than others, since the GARCH is more frugal and avoids overfitting. The rationale for being parsimonious may be explained in the way that taking the equation of conditional variance and subtracting one from each time subscript in the GARCH $(1,1)$ in equation (5), then subtracting 1 from all-time subscripts repeatedly. Afterward, $\sigma_{t-1}^{2}$ is substituted into equation (5), and the same procedure is followed for $\sigma_{t-2}^{2}, \sigma_{t-3}^{2}$, and so on, until the model can accommodate an infinite number of replacements in this manner.

$$
\begin{gathered}
\sigma_{\mathrm{t}}^{2}=\alpha_{0}+\alpha_{1} \mathrm{u}_{\mathrm{t}-1}^{2}+\beta_{1} \sigma_{\mathrm{t}-1}^{2} \\
\sigma_{\mathrm{t}-1}^{2}=\alpha_{0}+\alpha_{1} \mathrm{u}_{\mathrm{t}-2}^{2}+\beta_{1} \sigma_{\mathrm{t}-2}^{2}
\end{gathered}
$$

As a result, the GARCH $(1,1)$ model may be expressed in terms of an infinite number of observations, as given

$$
\sigma_{\mathrm{t}}^{2}=\gamma_{0}+\gamma_{1} \mathrm{u}_{\mathrm{t}-1}^{2}+\gamma_{1} \mathrm{u}_{\mathrm{t}-2}^{2}+\cdots
$$

For the q order ARCH model, this is a limitation. Therefore, the GARCH $(1,1)$ model is known as a parsimonious model that allows an infinite amount of prior squared errors to influence current conditional variances. Furthermore, the model has limited parameters in the conditional variance equation, as Bera and Haggins (1993) suggest.

Essentially, the GARCH $(1,1)$ model can be enlarged to the GARCH $(p, q)$ model, which is defined as the conditional variance at time $t$ parameterized using part information from the squared error ( $\mathrm{q}$ delays) and previous conditional variance information ( $\mathrm{p}$ lags).

The GARCH (p, q) is used to investigate price volatility for variables in this study. By including exogenous variables such as their $\mathrm{p}$ delays, crude oil, and exchange rates with $\mathrm{q}$ lags. It is important to know that this model may be used to predict the volatility of veal and lamb. For veal and lamb prices, two major conditional variance equations are basically created as endogenous variables in the model called the GARCH (p, q) model. Consequently, the equations are as follows:

$$
\sigma_{\mathrm{t}}^{2}=\alpha_{0}+\sum_{\mathrm{i}=1}^{\mathrm{q}} \alpha_{\mathrm{i}} \mathrm{u}_{\mathrm{t}-\mathrm{i}}^{2}+\sum_{\mathrm{j}=1}^{\mathrm{p}} \beta_{\mathrm{i}} \sigma_{\mathrm{t}-\mathrm{j}}^{2}
$$

Where;

$\boldsymbol{\sigma}_{t}^{2}$ : The conditional variance of the errors 
$\boldsymbol{u}_{\boldsymbol{t}-\boldsymbol{i}}^{2}$ : The previous value of the squared errors

$p$ : The lags of the conditional variance

$q$ : The lags of the squared error

$\sum_{i=1}^{q} \alpha_{i} u_{t-i}^{2}$ : The ARCH terms

$\sum_{j=1}^{p} \beta_{i} \sigma_{t-j}^{2}$ : The GARCH terms

\section{Empirical Results}

Table 2 presents the fundamental statistical information on real and log prices for veal, lamb, crude oil, and exchange rates, as well as a brief description of the variables' distribution characteristics. Lamb prices have a considerably greater standard deviation than veal prices, indicating a considerable variation, but both meat prices have a higher standard deviation than crude oil and exchange rates.

Table 2. Descriptive Statistics of the real and log price series

\begin{tabular}{lcccr}
\hline & Veal & Lamb & \multicolumn{1}{c}{ Oil } & Exchange Rates \\
\hline Real price series & & & & 1.778953 \\
Mean & 24.38955 & 27.46450 & 6.725718 & 1.642200 \\
Median & 23.97411 & 26.88483 & 6.978948 & 3.561602 \\
Maximum & 32.68018 & 40.60116 & 8.824677 & 1.086995 \\
Minimum & 19.63453 & 18.40775 & 4.393204 & 0.555659 \\
Std. Dev. & 2.690336 & 4.964737 & 0.947019 & 3.121364 \\
Skewness & 0.617241 & 0.525494 & -0.643230 & \\
Kurtosis & 2.797843 & 2.775577 & 2.725329 & 0.2315 \\
\hline Logarithm of real price series & & & 0.215426 \\
\hline Mean & 1.384646 & 1.43185 & 0.823 & 0.036228 \\
Median & 1.379743 & 1.429507 & 0.844 & 0.123987 \\
Maximum & 1.514284 & 1.608538 & 0.946 & 0.640962 \\
Minimum & 1.29302 & 1.265001 & 0.643 & 2.519591 \\
Std. Dev. & 0.046861 & 0.077353 & 0.065404 & \\
Skewness & 0.394992 & 0.134567 & -0.910266 & \\
Kurtosis & 2.511656 & 2.475756 & 2.944889 & \\
\hline
\end{tabular}

Table 3 shows the temporal trends for the Augmented Dickey-Fuller (ADF) unit root test in our empirical research. The ADF test gives the result of the non-stationarity situation because, for all variables in the model for the values of real and log prices, the null hypothesis cannot be rejected at the $1 \%, 5 \%$, or $10 \%$ significant level.

The first difference for the time series, on the other hand, is stationarity at a significant level. Thus the $H_{0}$ is rejected in which means that there is a unit root. Furthermore, the absolute critical values are smaller than the absolute value of the ADF test statistic at the $1 \%, 5 \%$, and $10 \%$ levels, which indicates that the test statistic is stationary.

The hypothesis is basically given as follows

$H_{0}$ : The variable includes unit roots

$H_{1}$ : The variable is stationary

Time series lag lengths are chosen using the Akaike Information Criterion (AIC). In terms of stationary, we must examine the lag number. Indifference, both real and log variables are stable, and the lags lengths for real and log prices in levels and differences are given in Table 3. For veal, crude oil, and exchange-rate prices, there is just one lag, but for lamb prices, three lags exist. For veal, lamb, crude oil, and exchange rates in terms of the log prices in differences, respectively, the lags number are two, three, one, and two. 
Table 3. ADF unit root tests result for real and log prices

\begin{tabular}{lcccccccc}
\hline & \multicolumn{4}{c}{ Real prices } & \multicolumn{4}{c}{ Log price in log } \\
\cline { 2 - 9 } & \multicolumn{2}{c}{ In levels } & \multicolumn{2}{c}{ In first difference } & \multicolumn{2}{c}{ In levels } & \multicolumn{2}{c}{ In first difference } \\
\cline { 2 - 9 } Series & $\begin{array}{c}\text { Test } \\
\text { statistic }\end{array}$ & Lags & Test statistic & Lags & $\begin{array}{c}\text { Test } \\
\text { statistic }\end{array}$ & Lags & Test statistic & Lags \\
\hline Veal & -2.91 & 2 & $-15.58^{* * *}$ & 1 & -2.69 & 0 & $-13.88^{* * *}$ & 2 \\
Lamb & -2.56 & 4 & $-10.15^{* * *}$ & 3 & -2.49 & 4 & $-10.33^{* * *}$ & 3 \\
Oil & -2.68 & 2 & $-17.06^{* * *}$ & 1 & -2.61 & 1 & $-16.80^{* * *}$ & 1 \\
Exchange & & & & & & & & \\
Rates & -0.91 & 1 & $-15.70^{* * *}$ & 1 & 0.76 & 3 & $-12.54 * * *$ & 2 \\
\hline
\end{tabular}

*** show the significance at the $1 \%, 5 \%$, and $10 \%$ significant level for the stationary test. The selection of Lags is based on the Akaike information criterion (AIC).

The ARCH effects test for residual estimation is depicted in Table 4. Firstly, a normal linear model $($ Eq. $(9,10))$ of real prices and log prices for both red meat products is run as given crude oil prices and exchange rates in either levels or differences into the right-hand side of equations. Secondly, we preserve the residuals, then square them, and regress them on "q" own lags to test the null hypothesis that there are no ARCH effects. The null hypothesis of no ARCH effects in both levels and differences is rejected as the findings reveal that time series of veal and lamb prices exhibit $\mathrm{ARCH}$ effects at the 5\% significant level.

$$
\begin{gathered}
\mathrm{Y}_{\text {veal }}=\beta_{0}+\beta_{1} \mathrm{X}_{\mathrm{oil}}+\beta_{2} \mathrm{X}_{\text {exchange_rates }} \\
\mathrm{Y}_{\text {veal }}=\beta_{0}+\beta_{1} \mathrm{X}_{\mathrm{oil}}+\beta_{2} \mathrm{X}_{\text {exchange_rates }} \\
\mathrm{Y}_{\text {lamb }}=\beta_{0}+\beta_{1} \mathrm{X}_{\mathrm{oil}}+\beta_{2} \mathrm{X}_{\text {exchange }} \text { rates } \\
\Delta \mathrm{Y}_{\text {lamb }}=\beta_{0}+\beta_{1} \Delta \mathrm{X}_{\mathrm{oil}}+\beta_{2} \Delta \mathrm{X}_{\text {exchange_rates }}
\end{gathered}
$$

Table 4. ARCH effects test result for the real and log prices

\begin{tabular}{lcccc}
\hline & \multicolumn{2}{c}{ Real prices } & \multicolumn{2}{c}{ Real price in logarithms } \\
\cline { 2 - 5 } \multicolumn{1}{c}{ Series } & In levels & In first differences & In levels & In first differences \\
\cline { 2 - 5 } Vest Statistic & Test Statistic & Test Statistic & Test Statistic \\
\multirow{2}{*}{ Veal } & 4084.23 & 46.86 & 4629.19 & 37.11 \\
& $(<0.001)$ & $(<0.001)$ & $(<0.001)$ & $(<0.001)$ \\
Lamb & 6730.71 & 52.10 & 6625.64 & 45.87 \\
\hline
\end{tabular}

Note: the p-value for each equation is presented in the brackets, shows the null hypothesis is rejected at a 5\% significant level.

The estimated parameters for the generalize $\operatorname{GARCH}(p, q)$ model are presented in Table 5. As regarding the result, we can see the coefficients estimate of the crude oil and exchange rates prices, and their lags are given as $\beta$, and the coefficients of an estimate of the lags of veal and lamb are given. We separately estimate the veal and lamb time series. The equations for veal and lamb are given as follows;

$$
\begin{gathered}
\text { Veal: } \mathrm{y}_{1 \mathrm{t}}=\mathrm{c}+\alpha_{1} \mathrm{y}_{1 \mathrm{t}-1}+\alpha_{2} \mathrm{y}_{2 \mathrm{t}-1}+\alpha_{3} \mathrm{y}_{1 \mathrm{t}-2}+\alpha_{4} \mathrm{y}_{2 \mathrm{t}-2}+\alpha_{5} \mathrm{y}_{1 \mathrm{t}-3}+\alpha_{6} \mathrm{y}_{2 \mathrm{t}-3}+ \\
\alpha_{7} \mathrm{y}_{1 \mathrm{t}-4}+\alpha_{8} \mathrm{y}_{2 \mathrm{t}-4}+\beta_{1} \mathrm{x}_{1 \mathrm{t}}+\beta_{2} \mathrm{x}_{2 \mathrm{t}}+\beta_{3} \mathrm{x}_{1 \mathrm{t}-1}+\beta_{4} \mathrm{x}_{2 \mathrm{t}-1}+\beta_{5} \mathrm{x}_{1 \mathrm{t}-2}+\beta_{6} \mathrm{x}_{2 \mathrm{t}-2}+ \\
\beta_{7} \mathrm{x}_{1 \mathrm{t}-3}+\beta_{8} \mathrm{x}_{2 \mathrm{t}-3}+\beta_{9} \mathrm{x}_{1 \mathrm{t}-4}+\beta_{10} \mathrm{x}_{2 \mathrm{t}-4} \\
\text { Lamb: } \mathrm{y}_{2 \mathrm{t}}=\mathrm{c}+\alpha_{1} \mathrm{y}_{1 \mathrm{t}-1}+\alpha_{2} \mathrm{y}_{2 \mathrm{t}-1}+\alpha_{3} \mathrm{y}_{1 \mathrm{t}-2}+\alpha_{4} \mathrm{y}_{2 \mathrm{t}-2}+\alpha_{5} \mathrm{y}_{1 \mathrm{t}-3}+\alpha_{6} \mathrm{y}_{2 \mathrm{t}-3}+\alpha_{7} \mathrm{y}_{1 \mathrm{t}-4}+ \\
\alpha_{8} \mathrm{y}_{2 \mathrm{t}-4}+\beta_{1} \mathrm{x}_{1 \mathrm{t}}+\beta_{2} \mathrm{x}_{2 \mathrm{t}}+\beta_{3} \mathrm{x}_{1 \mathrm{t}-1}+\beta_{4} \mathrm{x}_{2 \mathrm{t}-1}+\beta_{5} \mathrm{x}_{1 \mathrm{t}-2}+\beta_{6} \mathrm{x}_{2 \mathrm{t}-2}+\beta_{7} \mathrm{x}_{1 \mathrm{t}-3}+\beta_{8} \mathrm{x}_{2 \mathrm{t}-3}+\beta_{9} \mathrm{x}_{1 \mathrm{t}-4} \\
\beta_{10} \mathrm{x}_{2 \mathrm{t}-4}
\end{gathered}
$$


In the case of veal prices, the crude oil prices at time $t, t-1$, and $t-3$ have a significant effect at a $1 \%$ significance level, and crude oil at time $t-4$ is significant at a $5 \%$ significance level. The veal prices are significantly affected by its previous periods $(t-1, t-2$, and $t-3)$.

On the other hand, for the lamb time series, the crude oil prices at time $t, t-1$, and $t-3$ have a significant effect on lamb prices at a $1 \%$ significance level. Additionally, exchange rates at times $t-2$ and $t-4$ have a significant effect on lamb prices at $1 \%$ and $5 \%$ significance levels, respectively. The lamb prices are significantly affected by its previous periods $(t-1, t-2$, and $t-3)$ and the previous period of veal prices $(t-1$ and $t-2)$.

Table 5. Estimated parameters for the generalize GARCH model

\begin{tabular}{|c|c|c|c|c|c|}
\hline $\begin{array}{l}\text { Dependent } \\
\text { variables }\end{array}$ & $\begin{array}{l}\text { Independent } \\
\text { variables }\end{array}$ & Coefficient & $\begin{array}{l}\text { The Estimate } \\
\widehat{\boldsymbol{\beta}} \text { and } \widehat{\alpha}\end{array}$ & Std. error & t-statistics \\
\hline \multirow{19}{*}{ Veal } & oil $_{t}$ & $\beta_{1,1}$ & 1.056 & 0.119 & $* * * 8.874$ \\
\hline & $\operatorname{exch}_{t}$ & $\beta_{21}$ & 0.084 & 0.422 & 0.200 \\
\hline & $o i l_{t-1}$ & $\beta_{3,1}^{2.1}$ & -1.445 & 0.168 & $* * *-8.603$ \\
\hline & $\operatorname{exch}_{t-1}$ & $\beta_{4,1}$ & -1.037 & 0.667 & -1.555 \\
\hline & oil $_{t-2}$ & $\beta_{5.1}$ & 0.149 & 0.142 & 1.046 \\
\hline & $\operatorname{exch}_{t-2}$ & $\beta_{6,1}$ & 0.465 & 0.654 & 0.710 \\
\hline & oil $_{t-3}$ & $\beta_{7,1}$ & 0.420 & 0.160 & $* * * 2.626$ \\
\hline & $\operatorname{exch}_{t-3}$ & $\beta_{8,1}$ & 0.940 & 0.684 & 1.375 \\
\hline & oil $_{t-4}$ & $\beta_{9,1}$ & -0.182 & 0.091 & $* *-2.001$ \\
\hline & $\operatorname{exch}_{t-4}$ & $\beta_{10,1}$ & -0.415 & 0.436 & -0.952 \\
\hline & veal $_{t-1}$ & $\alpha_{1,1}$ & 0.954 & 0.026 & $* * * 36.027$ \\
\hline & $\operatorname{lamb}_{t-1}$ & $\alpha_{2,1}$ & 0.024 & 0.017 & 1.479 \\
\hline & veal $_{t-2}$ & $\alpha_{3,1}$ & 0.133 & 0.033 & $* * * 4.028$ \\
\hline & $\operatorname{lamb}_{t-2}$ & $\alpha_{4,1}$ & -0.024 & 0.022 & -1.112 \\
\hline & veal $_{t-3}$ & $\alpha_{5,1}$ & -0.152 & 0.035 & $* * *-4.413$ \\
\hline & $l a m b_{t-3}$ & $\alpha_{6,1}$ & -0.007 & 0.019 & -0.379 \\
\hline & veal $_{t-4}$ & $\alpha_{7,1}$ & 0.037 & 0.023 & 1.605 \\
\hline & $\operatorname{lamb}_{t-4}$ & $\alpha_{8.1}$ & 0.018 & 0.014 & 1.338 \\
\hline & constant & $\mathrm{c}$ & 0.335 & 0.254 & 1.318 \\
\hline \multirow{19}{*}{ Lamb } & oil $_{t}$ & $\beta_{1,2}$ & 1.341 & 0.128 & $* * * 10.495$ \\
\hline & $\operatorname{exch}_{t}$ & $\beta_{2,2}$ & -0.056 & 0.449 & -0.126 \\
\hline & oil $_{t-1}$ & $\beta_{3.2}$ & -1.776 & 0.176 & $* *-10.097$ \\
\hline & $\operatorname{exch}_{t-1}$ & $\beta_{42}$ & -1.033 & 0.692 & -1.493 \\
\hline & oil $_{t-2}$ & $\beta_{5,2}^{4,2}$ & -0.082 & 0.148 & -0.552 \\
\hline & $\operatorname{exch}_{t-2}$ & $\beta_{6,2}$ & 1.928 & 0.681 & $* * * 2.831$ \\
\hline & $o i l_{t-3}$ & $\beta_{7,2}$ & 0.510 & 0.191 & $* * * 2.665$ \\
\hline & $\operatorname{exch}_{t-3}$ & $\beta_{8,2}$ & -0.062 & 0.661 & -0.093 \\
\hline & $o i l_{t-4}$ & $\beta_{9,2}$ & -0.045 & 0.109 & -0.413 \\
\hline & $\operatorname{exch}_{t-4}$ & $\beta_{10.2}$ & -0.832 & 0.415 & $* *-2.004$ \\
\hline & veal $_{t-1}$ & $\alpha_{1,2}$ & 0.105 & 0.029 & $* * * 3.598$ \\
\hline & $\operatorname{lamb}_{t-1}$ & $\alpha_{2.2}$ & 0.973 & 0.020 & $* * * 49.281$ \\
\hline & veal $_{t-2}$ & $\alpha_{3,2}$ & -0.075 & 0.039 & $*-1.940$ \\
\hline & $\operatorname{lamb}_{t-2}$ & $\alpha_{4,2}$ & 0.093 & 0.025 & $* * * 3.675$ \\
\hline & veal $_{t-3}$ & $\alpha_{5.2}$ & -0.041 & 0.036 & -1.153 \\
\hline & $\operatorname{lamb}_{t-3}$ & $\alpha_{6,2}$ & -0.056 & 0.021 & $* * *-2.650$ \\
\hline & veal $_{t-4}$ & $\alpha_{7,2}$ & 0.001 & 0.027 & 0.036 \\
\hline & $\operatorname{lamb}_{t-4}$ & $\alpha_{8,2}$ & -0.013 & 0.016 & -0.808 \\
\hline & constant & $\mathrm{c}$ & 0.807 & 0.258 & $* * * 3.129$ \\
\hline
\end{tabular}

Note: $* * * * *, *$ show the significance at the $1 \%, 5 \%$ and $10 \%$ level respectively.

The model is selected by considering the highest logarithm marginal likelihood as well as the highest R-square value (Table 6). The condition number of the design matrix, which is defined as a 
measure of the sensitivity of a function in terms of changes and errors, and an indication of multicollinearity.

Table 6. The logarithm of the marginal likelihood
The condition number of the design matrix
6398.518
R-square
0.972
Logarithm of the marginal likelihood

The volatility report for veal from the preferred model estimated is displayed in Figure 2. the horizontal axis reports the weekly time period between 2006, May, and 2017, Feb. The vertical axis reports the veal variance value of the estimation with a weekly time period ranging from 1 to 558. The figure clearly shows that veal prices are somewhat volatile during the period, and the highest volatility is estimated in period number 205 that exists in 2010 . The veal prices are mostly volatile between the period number of $200^{\text {th }}$ week and $300^{\text {th }}$ week consisting at the year 2010 and 2011.

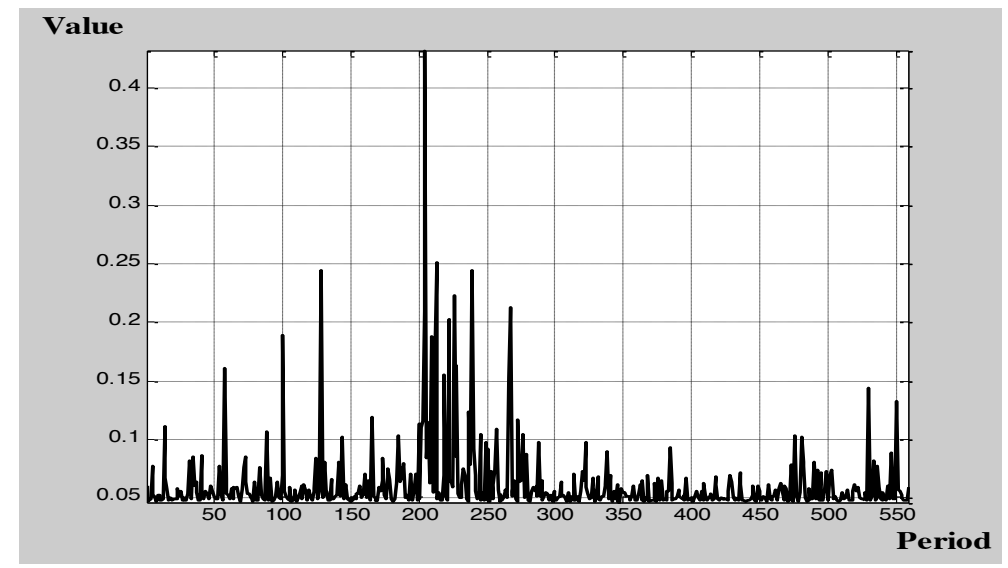

Figure 2. Volatility plot of veal variance.

The volatility report for lamb from the preferred model estimated is given in Figure 3 . The horizontal axis reports the weekly time period ranging from 1 to 558, and the vertical axis reports the value of the estimate. The figure explicitly indicates that lamb prices are volatile during the period, and the highest volatility is estimated in period number 322 that exists in 2012 . The lamb prices are mostly volatile between the period number of 150 and 350 in 2009 and 2012.

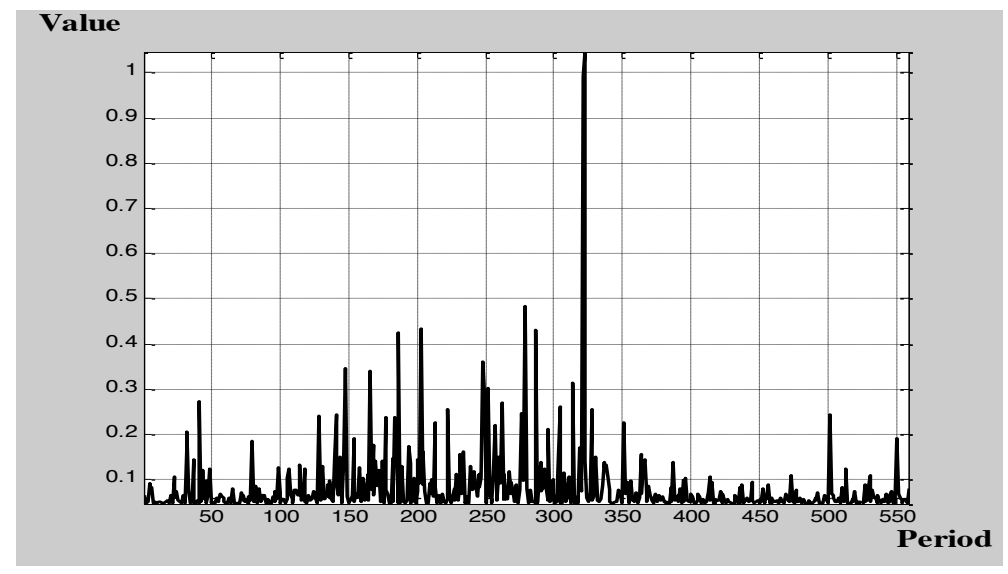

Figure 3. Volatility plot of lamb variance.

The volatility report for cross-correlation between veal and lamb is given in Figure 4. The horizontal axis reports the weekly time period ranging from 1 to 558, and the vertical axis reports the 
value of the estimate. The correlation between veal and lamb is strong, as we can see in Figure 4. The veal prices have a negative and positive correlation with lamb prices during the given periods.

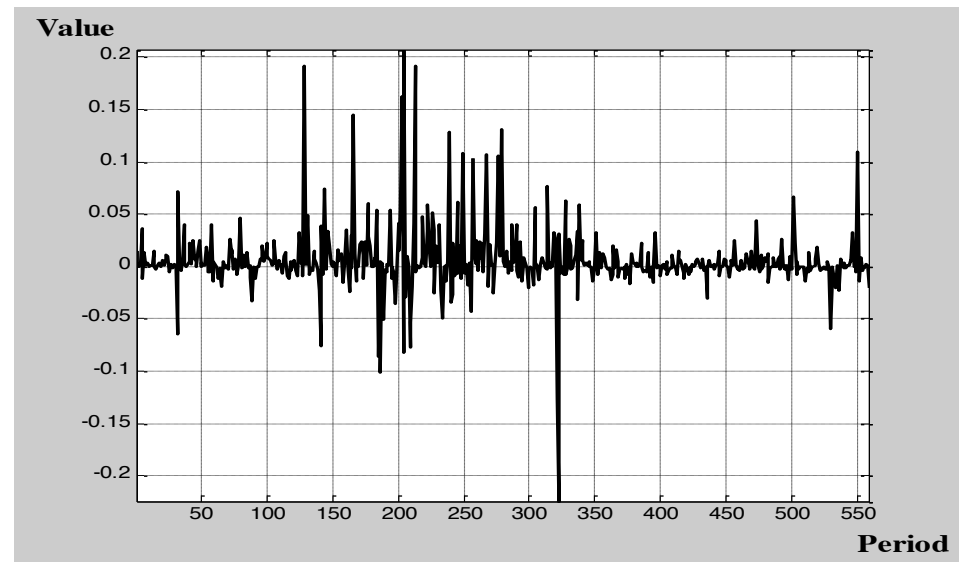

Figure 4. Volatility plot of cross correlation between veal and lamb time series.

\section{Conclusion}

Red meat production and prices have been an important issue in Turkey because of many reasons, such as the increase in red meat prices, insufficient production, and speculation in red meat markets. Another issue is that the demand for red meat is not entirely met by the local supply, which fundamentally causes an increase in red meat prices. In actual fact, even though the Turkish government has continued to support red meat producers in order to increase production and reduce costs, prices have not declined.

With the increase in red meat prices, it has mainly demonstrated fluctuation over time. The changes are affected by many linear or non-linear factors. The literature on the effects of agricultural prices focuses mostly on the linear aspect by frequently embracing price determination. However, we investigate two relationships. First, the link between crude oil and red meat prices; second, the link between exchange rates and red meat prices in Turkey. With respect to this relationship, we review many studies associated with the volatility transmission between agricultural and energy commodity prices because energy commodities are likely to affect at least some agricultural commodities.

Previous empirical research has shown that agricultural and energy commodity prices move in lockstep in the short and long term. The change in crude oil prices and its volatility has a significant role in economic and financial markets. On the other hand, the linkage between crude oil and exchange rates in Turkey occurs since Turkey depends on importing oil, which is related to the transportation and processing of red meat products as a significant input. Therefore, we assume there might be a linkage between exchange rates and red meat prices because Turkey depends on importing crude oil and has started to import red meat products, especially after 2010 with the abrogation of tax on red meat import.

Volatility in commodity prices movements is defined as embracing change either low or high levels over time. This might cause a clustering behaviour that is explained as the large or small changes followed by large or small changes in the time series (Engle et al., 1990). The study also uses ADF tests. The results show that the variables in real and log prices are stationary in first differences. The ADF test is also used to select lag lengths exhibiting different numbers for each time series. For volatility modeling, the GARCH (p, q) model is one of the more practical ways to assess volatilities. We find, however, that the GARCH (p, q) model does not slightly dominate and fixes the data as much as the simple linear model with vector auto-regressions. Additionally, the ARCH effects in the model are found to the significant compared to the null hypothesis of no ARCH effects. Although the presence of the ARCH effects provides evidence to construct GARCH models, from an empirical point of view, we generalize the GARCH (p, q) model to one embracing different variance effects on the equal of all time periods.

One of the study's major findings is that both veal and lamb prices are subject to substantial volatility, particularly between 2009: 200 (year: week) and 2012: 350, and that crude oil prices have a 
significant influence on veal and lamb prices, as well as prices in earlier times. Furthermore, exchange rate lags have a substantial impact on lamb prices but not on veal prices.

Another key finding of our results is that they might be important to examine the relationship between prices and policy and permit policymakers to put policy implementation into efficient practice. Finally, as related previous studies during the literature review, the author has examined increases in food price volatilities and related that policy follow-up has primarily been useful in advancing the prices of agricultural production and their volatilities.

\section{References}

An, H., Qiu, F., \& Zheng, Y. (2016). How do export controls affect price transmission and volatility spillovers in the Ukrainian wheat and flour markets? Science Direct, 142-150.

Bergmann, D., O'Connor, D., \& Thümmel, A. (2016). An analysis of price and volatility transmission in butter, palm oil and crude oil markets, Agricultural and Food Economics, DOI 10.1186/s40100-016-0067-4

Chadwick, M. G., \& Baştan, E. M. (2017). Beef price volatility in Turkey : can import policy affect the price and its uncertainty? (17/09), Central Bank of the Republic of Turkey, Ankara.

Çınar, G., \& Hushmat, A. (2016). Impact of volatility of world oil prices on Turkey's Food Prices: Garch Approach, Global Journal of Economics and Business Studies, 9(5), 1-8.

Damba, O. T., Bilgic, A., \& Aksoy, A. (2017). Estimating price volatility transmission between world crude oil and selected food commodities. A BEKK approach, 48(1), 41-49.

Dickey A. D., \& Fuller W. A. (1979). Distribution of the estimators for autoregressive time series with a unit root. Journal of American Statistical Association, 74(366), 427-431.

Engle, R. F., Ng, V. K., \& Rothschild, M. (1990). Asset pricing with a factor-ARCH covariance structure: Empirical estimates for treasury bills. Journal of econometrics, 45(1-2), 213-237.

FAO, (2010). Price volatility in agricultural markets: evidence, impact on food security and policy responses. http://www.fao.org/docrep/013/am053e/am053e00.pdf.

FAO, (2017). Food and Agriculture Organization of the United Nations. Internatinal Crude Oil Prices. http://www.fao.org/giews/food-prices/indicators/detail/en/c/235344/. Access date: 26 July 2017.

Gardebroek, C., \& Hernandez, M. A. (2013). Do energy prices stimulate food price volatility? Examining volatility transmission between US oil, ethanol and corn markets. Energy Economics, 40, 119-129.

Harri, A., Nalley, L., \& Hudson, D. (2009). The relationship between oil, exchange rates, and commodity prices. Journal of Agricultural and Applied Economics, 501-510.

Harris, R., \& Sollis, R. (2003). Applied Time series modelling and forecasting, West Sussex, England, John Wiley and Sons, p. 41.

Hassan, S. A., \& Malik, F. (2007). Multivariate GARCH modelling of sector volatility transmission, Quarterly Review of Economics and Finance, 47(3), 470-480.

Hassouneh, I., Serra, T., \& Gil, J. M. (2010). Price transmission in the Spanish bovine sector: the BSE effect. Agricultural Economics, 41(1), 33-42.

Hayenga, M. L., \& Dipietre, D. D. (1982). Hedging wholesale meat prices: Analysis of basis risk. Journal of Futures Markets, 2(2), 131-140.

Kaltaloglu, M. (2010). Price transmissions between food and oil. M.B.A., in partial fulfilment of the requirements for the degree of master of business administration in the Department Of Business Administration.

Nazlioglu, S., \& Soytas, U. (2012). Oil price, agricultural commodity prices, and the dollar: A panel cointegration and causality analysis. Energy Economics, 34(4), 1098-1104.

Nazlioglu, S., Erdem, C., \& Soytas, U. (2013). Volatility spillover between oil and agricultural commodity markets. Energy Economics, 36, 658-665.

Republic of Turkey Ministry of Foreign Affairs, (2017). Retrieved from 2017, May http://www.mfa.gov.tr/turkeys-energy-strategy.en.mfa.

Serra, T., \& Goodwin, B. K. (2003). Price transmission and asymmetric adjustment in the Spanish dairy sector. Applied economics, 35(18), 1889-1899. 
TIM. (2017). Türkiye İhracatçılar Meclisi (Turkish Exporters Assemply), Agricultural Sector and Policy in Turkey (380-384). İstanbul. Retrieved from http://www.tim.org.tr/files/downloads/Raporlar/Tarim_Raporu_2017.pdf.

TUIK, (2017). Turkish Statistical Institutes, Foreign Trade Statistics Database, Product-Partner Countries in Trade, http://rapory.tuik.gov.tr/22-07-2017-15:20:34$1365891871791902376266888507 . \mathrm{html}$ ?.

USDA, (2016). Turkey Livestock and Products Report. http://agriexchange.apeda.gov.in/marketreport/Reports/Livestock_and_Products_Annual_An kara Turkey 8-31-2016.pdf. Retrieved May, 2017.

Yavuz, F., Bilgic, A., Terin, M., \& Guler, I. O. (2013). Policy implications of trends in Turkey's meat sector with respect to 2023 vision. Meat science, 95(4), 798-804. 